\title{
Devolving responsibilities for human resources to line management? An empirical study about convergence in Europe*
}

Wolfgang Mayrhofer, Michael Müller-Camen, Johannes Ledolter, Guido Strunk, Christiane Erten

The lively debate about converging or diverging management practices is not yet decided. Human resource management (HRM) is no exception. Using the widely discussed issue of HR specialists handing over HR tasks to line management as an example, the article analyses whether European companies in the last decade have adopted similar HR practices and whether successful European companies are similar to each other in this respect. The results show that there is no trend towards convergence in Europe. Furthermore, various configurations of HR practices characterise successful organisations. Both results have important consequences for $H R$ academics and practitioners, especially in the Central and Eastern European countries.

Die umfangreiche Debatte über Konvergenz bzw. Divergenz im Management allgemein bzw. im HRM im Besonderen ist nicht entschieden. Am Beispiel der Verlagerung von Personalaufgaben von zentralen Fachabteilungen auf das Linienmanagement geht der Artikel der Frage nach, inwieweit Unternehmen in Europa im letzten Jahrzehnt ähnliche Personalpraktiken eingesetzt haben und wie sehr sich erfolgreiche Unternehmen in dieser Hinsicht ähneln. Die Resultate zeigen keine konvergierenden Entwicklungen in Europa. Weiters zeigt sich, dass erfolgreiche Unternehmen durch sehr unterschiedliche Konfigurationen von Personalpraktiken gekennzeichnet sind. Beide Resultate sind für die Personalforschung und -praxis vor allem auch in den mittel-und osteuropäischen Ländern von Bedeutung.

Key Words: Empirical research / Human resource management / Organisational performance, Europe / International comparative studies

\footnotetext{
*Manuscript received: 25.09.03, revised: 03.03.04, accepted: 04.03.04
} 


\section{Introduction**}

The lively debate about converging or diverging management practices is not yet decided. Advocates of convergence argue that due to factors like globalisation, technological developments or economic rationality on can see an increasing similarity between organisational forms and management practices (Kerr et al. 1960; Engwall 2000). Counter arguments claim that different institutional frameworks, e.g., legal systems, systems of corporate governance, or educational systems, lead to diverse local forms of management (Whitley 1994). In Europe, this debate has an internal as well as an external point of reference. The internal perspective covers the development in different European countries. Through the European Union (EU), its affiliates and the prospective members, the issue of common standards has been raised in various areas and become important. The external perspective puts its emphasis on the comparison between Europe and other important economic and political actors, especially the United States and Japan. Some researchers even see a distinct European model evolving (e.g., Brewster 1994a) question the tendency towards an increasing identity of North-American and European management practices (Sparrow/Hiltrop 1997; Müller 1999).

\footnotetext{
** Wolfgang Mayrhofer, born 1958, Professor of Management and Organisational Behaviour, Vienna University of Economics and Business Administration. Main research topics: Career research, international comparative research on human resource management; social systems theory and management. Corresponding address: wolfgang.mayrhofer@wuwien.ac.at
}

Michael Müller-Camen, born 1962, Associate Professor of International Management, School of Business Administration, International University in Germany. Main research areas: international and comparative management, human resource management, diversity management and higher education management. Corresponding address: michael.mullercamen@i-u.de

Johannes Ledolter, John F. Murray Research Professor, University of Iowa, Iowa City, USA. Main research areas: statistical applications in business, applied time series analysis, forecasting, probability and statistics for engineering and physical sciences, statistical methods for quality and productivity improvement. Corresponding address: johannesledolter@uiowa.edu

Guido Strunk, born 1968, assistant professor, Interdisciplinary Department of Management and Organisational Behaviour, Vienna University of Economics and Business Administration. Main research areas: career research, international comparative research on human resource management, chaos theory.Corresponding address: guido.strunk@wuwien.ac.at

Christiane Erten: born 1962, lecturer at the Interdisciplinary Department of Management and Organisational Behaviour, Vienna University of Economics and Business Administration. Main research areas: intercultural management $\&$ training, group dynamics, organisational development. Corresponding address: certen@atconsult.net 
The convergence-divergence debate as a part of the more general phenomenon of diffusion of concepts, tools, ideas etc. is fuelled not only by theoretical controversy, but also by a number of practical 'real life' factors. Among the most important are the globalisation of business over the past decades, the creation of large institutions like the EU, or North American Free Trade Agreement (NAFTA) and an increasing competitive pressure companies face.

The globalisation of business is closely linked with the rise of internationally or globally operating companies. Not only the obvious examples of well known global players like ABB, IBM, Volkswagen or Coca Cola, but to an increasing extent also smaller firms make their business in markets that by far transcend national and regional borders. One of the classic issues within these companies is the tension between standardisation and localisation. While standardisation supports economies of scale and scope or flatter learning curves, localisation tailors processes and products to the context in which the business units are located. Standardised processes promote converging developments, whereas localisation is a force towards greater divergence of developments.

The large evolving institutions like EU or NAFTA only can exist if a core of joint procedures and regulations exist. For example, the existing legal regulations within the EU relating to the contract award process, the social regulations or the recruitment of personnel are just a few examples for a tendency towards a more unified legal codex in the member states. In turn, such regulations exert a strong influence towards at least partly similar processes in the companies.

Increasing competitive pressure at the national and the international level comes from a number of sources (e.g., Czinkota et al. 1994). The emergence of large trading blocks like the ones mentioned above increase the market size dramatically. In turn, this may lead to a lower degree of monopoly because a larger market will increase the number of companies competing with each other. In addition, less productive economies are challenged by such developments. Market transparency for customers has greatly increased. For example, the Euro enables customers to compare prices within the Euro zone across a number of different national states with great ease. Likewise, the existence of the internet and the increasing accessibility of the internet throughout the world contribute to the transparency of the markets. It is comparatively easy and cheap for customers to get essential information within a short time. Thus, companies know that they can no longer reckon with uninformed customers that have no choice. Last, but not least the volatility of international capital seeking to gain a maximum return keeps companies on their feet. Companies know that they have to deliver good financial results in order to keep their shareholders. Thus, overall organisational performance becomes increasingly crucial.

Among the different areas of management, analysing the diffusion of human resource management (HRM) concepts and their convergence/divergence as 
well as their link to organisational performance is especially interesting. On the one hand, people seem to be one of those organisational resources that are less prone to standardisation because of differentiating factors like personality or national culture. On the other hand, human resources are regarded as one of the crucial organisational success factors. As such, HR processes should be no exception when it comes to standardisation. Given this spectrum, HRM seems to be a good example for discussing the question of diffusion of management concepts since the incentive for companies to 'streamline' processes in these areas is great, yet there are certain barriers that restrict such efforts.

The current paper builds upon these considerations and focuses on the area of the diffusion of HRM concepts in Europe. More specifically, it empirically analyses converging or diverging developments in $\mathrm{HR}$ and its relation to performance. Using the widely discussed issue of HR specialists handing over HR tasks to line management as an example, it deals with two questions:

1. Have European companies in the last decade adopted more similar ways of sharing the responsibility between HR specialists and line management?

2. Do successful European companies have a common way of sharing the responsibility between HR specialists and line management?

\section{Conceptual background}

In spite of the growing debate at the European and global level about the existence of converging or diverging tendencies in society and its subsystems, it is by no means clear what is meant by convergence/divergence and which theoretical considerations constitute the basis for such developments. Organisational theory is no exception. This section will explore theoretical positions and their empirical operationalisation.

\subsection{Convergence and divergence}

\subsubsection{Theoretical positions}

- Convergence

Proponents of convergence theory argue that the logic and constraints of market economy and technology of production is the main force that does not allow organisations to deviate from 'good', 'accepted' management practices (Kidger 1991). Thus, differences due to historical, geographical or cultural reasons will disappear. There will be absolute uniformity. However, once differences in terms of sector, strategy or resources available for the organisations are taken into account, a tendency towards similar solutions for similar problems will emerge. 
The often tacit assumption behind most of convergence thinking is the existence of 'invisible hands' that guide organisational processes and behaviour. Most often, these 'invisible hands' serve the purpose of economic rationality and efficiency.

Historically, a number of prominent advocates implicitly or explicitly have taken this point of view, among them, for example, Max Weber, Henry Fayol or Frederick W. Taylor (see Weber 1980; Weber 1988 [Orig. 1917]; Fayol 1916; Fayol 1985; Taylor 1919).

In more recent times, a number of arguments have emerged that also point towards convergence. Some focus on managers and their role as specific type of organisational member leading to more unified organisational practices (for an overview see Frech et al. 1996). Transaction cost theory (Williamson 1975) argues that firms with similar or identical transaction costs develop similar organisational forms (Hollingsworth/Boyer 1997: 34). Likewise, the 'structure follows strategy' position points towards unifying forces of similar environments (see, e.g., Chandler Jr. 1962; Chandler Jr. 1977). In addition, some argue that the United States can be regarded as a long-time leader in the area of technological development and economic prosperity, thus serving as a 'role model' for other countries (Kerr et al. 1960; Locke et al. 1995).

- Divergence

In direct contrast, the divergence thesis emphasises the factors that lead to different developments in organisations and countries. For example, from an institutionalist perspective variables like the institutional framework, e.g., legal regulations, powerful 'local' actors, or specific societal norms constrain organisational or managerial freedom of action, thus producing different solutions for the same organisational problems (Meyer/Rowan 1977; DiMaggio/Powell 1983). Divergence theoreticians would argue that it is not primarily the economic rationality detached from the concrete context an organisation is operating in but rather the societal context - including elements like social norms and values, law system, or demographic composition of the work force - that determine how organisations act (Whitley 1994). Only if these variables are similar, converging developments are to be expected. From an institutional perspective, the main focus is on the importance of the national institutional context and its consequences for the behaviour of organisations. Some recent studies have shown this influence (e.g., Gooderham et al. 1999; Kostova/Roth 2002).

- Hybridisation

The situation within the European Union is very specific. In some areas this institution has been given the power to create a more unified context within which organisations have to operate (Brewster 1994a; Brewster 1994b). Nevertheless, national institutions and individual countries still have room to 
manoeuvre. Therefore, within the common framework different solutions will occur at the national and/or organisational level. In this way, a European hybrid model emerges. It is based on the assumption that there are forces from the market, technology and institutional context that promote convergent developments. At the same time, the cultural and institutional context at the national level promotes a more differentiated European picture in the area of management practices. Findings for convergent as well as divergent tendencies of management practices in Europe might be interpreted as two sides of the same coin (for a similar view of convergence and divergence occurring simultaneously see, e.g., Fombrun 1986: 414). This thinking suggests that simultaneously management practices in Europe become more alike in certain areas ('convergence') and stay or become different in other areas ('divergence').

\subsubsection{Empirical conceptualisation}

The question of operationalisation arises when we turn to empirical investigation: What is meant empirically when we talk about converging or diverging development in various countries? We propose that one can differentiate between at least two different forms of convergence: directional convergence (type I) and final convergence (type II) ${ }^{1}$.

Table 0. Directional convergence (type 1) - illustration of basic mechanism

\section{Development over time}

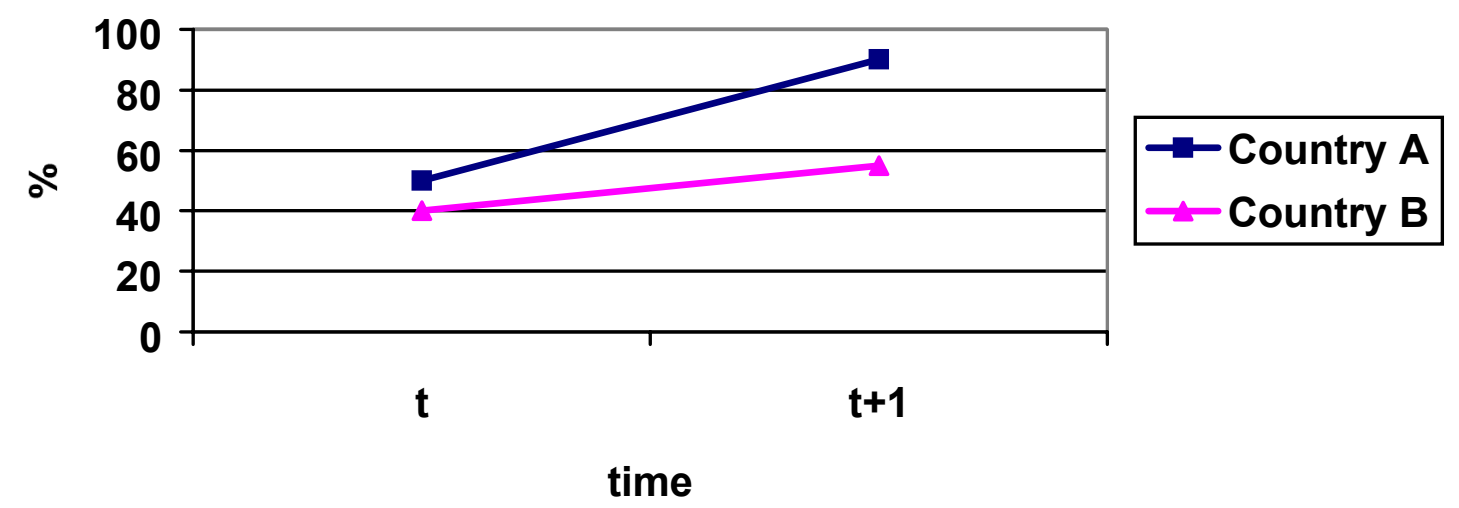

${ }^{1}$ Obviously, mutatis mutandis the same is true for divergence. For a third type of convergence, majority convergence, see Mayrhofer et al. 2002. 
- Type 1 - directional convergence

When comparing the developments between various countries one can speak of directional convergence if the development tendency goes into the same direction. Regardless of a starting level in each country the variable analysed changes in the same direction in each country. Table 1 shows the basic idea using an example to illustrate the idea.

As one can see from the table, in both countries A and B the development over time of, e.g., the frequency of use of a certain instrument, points into the same direction: the instrument is increasingly being used. Nevertheless, in absolute terms the frequency of use in the two countries is at a different level. Thus, the direction of the development is the same, yet the countries differ in absolute values.

- Type 2 - final convergence

Final convergence (type 2) emerges if the development of a variable in different countries points towards a common end point. In other words, the differences between countries decrease. This development is independent of directional convergence (type 1) as different developments in terms of, for example, frequency of use of a certain management tool, still can result in final convergence. Table 2 shows three country pairs as examples for different cases of final convergence.

Table 2. Final convergence (type 2) - illustration of basic mechanism

\section{Development over time}

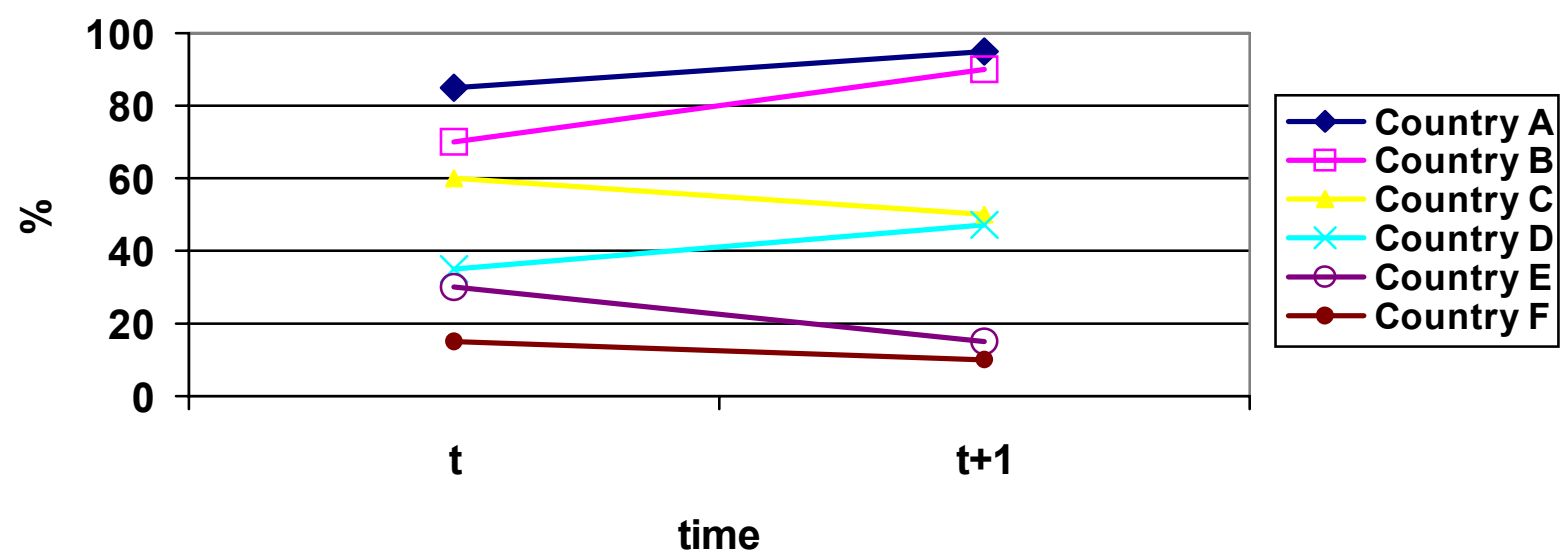

The two trend lines in the upper half (countries A and B) show a first case where the development at time $t$ starts at a different absolute level. After the start, it continually moves in the same direction (increase, thus directional convergence) and towards a common endpoint where there is less difference in absolute terms. Hence, final convergence occurs. The two trend lines in the 
middle (countries C and D) illustrate a different case. Again, the starting point is different in absolute terms. However, the direction of development - a decrease in country $\mathrm{C}$ and an increase in country D - is different. In other words, there is no directional convergence. Nevertheless, final convergence emerges: the development in both countries point towards a common endpoint, again reducing the difference between the two countries in absolute numbers. The third illustration with countries $\mathrm{E}$ and $\mathrm{F}$ is similar to the first one, only this time there is a common decrease in frequency. Nevertheless, directional (both developments point in the same direction) and final (the development runs towards a common endpoint) convergence occurs.

\subsection{Decentralisation of human resource activities}

A common theme in much of the management literature and practitioner rhetoric is the replacement of centralised, bureaucratic and hierarchical structures by more flexible, decentral, project oriented forms where information networks and ,the culture glue are more important than formal rules and regulations (Zenger/Hesterly 1997). Various aspects are linked with this. First, companies retain only the core competencies within the firm while outsourcing most low value-added activities. Second, front-line managers are provided with greater autonomy. They are allowed "to design their own jobs, fix their own processes, and do whatever it takes to satisfy a customer" (Hamel/Prahalad 1994: 290). Hence, these new organisational forms question the degree to which responsibility between line and staff functions is shared (Mayrhofer 1999). Third, there is much less emphasis on hierarchies which generally become much flatter. Hierarchies that have become too expensive and impeded information flows are partly substituted by more flexible, project-based forms of organisation (Whittington et al. 1999). Fourth, formal and informal information networks bind the autonomous units together (Chakravarthy/Gargiulo 1998: 438).

Such a change requires, among others, new ways of co-ordination and control in order to support the integrative element in a 'fluid' and diverse organisation (Drumm 1996). Linked with this is the devolvement of responsibilities for decision making and the devolvement of operative action from central, specialised units with expert knowledge to line management or even the employee 'down the line'. Some even argue that decisions about the allocation of all resources should be assigned to front-line managers (Hamel/Prahalad 1994).

HRM is not left untouched by these developments (see, e.g., Brewster et al. 2000, Scholz 1995). The move towards assigning more decision making power to line management has its HR facet: the HR department has to think about new ways of supplying the necessary services, performing its functions and equipping line managers with the necessary skills and competencies to handle 
the new HR tasks that they are confronted with. For quite some time this issue has been discussed in the literature (see e.g. Walker 1989, Brewster et al. 1997). It is argued that line managers play a key role within major areas of HRM like recruitment and selection, retention, development, compensation and lay off. Due to the closeness of line managers to the employees and their first hand insight responsibility should not left solely to human resources specialists. HR specialists are moving into a role of co-ordinator and catalyst for HR related activities of line managers - "management team player[s] working (jointly) with the line manager solving people-related business issues" (Schuler 1990: 51).

The rationale for this development seems to be quite convincing. First, there is some logic to the argument that there should be a unity of responsibility for and decision about resources. Those who have immediate access to resources, insight into the daily needs and make the decisions accordingly should also have the primary responsibility. Human resources are no exception here. Second, for many organisations personnel costs are a large part of their operating costs. Increasing cost pressure leads to a tendency of reduction of indirect, not directly ,productive' employees, often located in central specialist units. Therefore, the pressure to include more of the management of human resources into line management responsibilities with the intended side-effect of reducing HR staff increases. Third, the assignment of HR activities to the line managers' task portfolio increases their effectiveness. Given that line managers have the most immediate and up to date information about the employees " competence and represent the company to the employees, providing them with authority and responsibility to cover all or at least many crucial aspects of HR work gives them a greater impact on the employees' behaviour. Therefore, modern HRM has two components: To "... the strategic business policy decision-making activity designed to ensure a coherent and integrated approach to the overall management of the organization ... the generic responsibility of line or general managers for the day-to-day 'people-management' activities" (Kennoy, 1990: 7) is added. Both of these elements should contribute to increasing organisational performance.

\section{Hypotheses}

The remainder of the paper empirically analyses whether an increased decentralisation of HR activities, i.e., a devolvement of responsibilities from HR specialists to line management, can be observed and if this is positively linked with organisational performance. Specifically, we will test for directional (type 1) and final (type 2) convergence for the devolvement of responsibility away from central HR specialists towards line management and analyse whether such a devolvement is positively related to overall organisational performance. Our analysis will be guided by three hypotheses.

- Directional convergence 
In line with a general decentralisation of HRM one can expect that parts of the responsibility as well as operative tasks will no longer be assigned to technical specialists in the HR department. Instead, line management will increasingly take over these tasks. Therefore, the following hypothesis can be formulated:

\section{Hypothesis 1}

The percentage of European companies devolving HRM responsibility away from specialists towards line management has increased over the past decade.

- Final convergence

In addition, we propose that companies in European countries not only use line managers to an increasing extent for HR tasks, but also that differences between countries decrease. Thus, a common model of European HRM starts to evolve. This leads to the following hypothesis:

\section{Hypothesis 2}

The differences between countries in the degree of devolving HRM responsibility away from specialists towards line management are smaller at the end of the analysed time span than at the beginning.

- Devolvement of responsibility and organisational performance

Relating to organisational performances, we argue that the devolvement of HR responsibility to line management - a recommendation in HR often equated with successful HR management - is used by successful organisations. This results in the following hypothesis:

\section{Hypothesis 3}

A greater devolvement of HRM responsibility from specialists towards line management is positively linked with good organisational performance.

\section{Methodology}

\subsection{Database}

The data used for our analysis has been generated by the Cranfield Network on European Human Resource Management (Cranet-E), a research network dedicated to analysing developments in HRM in public and private organisations with more than 200 employees in a national, cross-national and quasi-longitudinal way since 1989 (see Brewster/Hegewisch 1994, Brewster et al. 2000, Brewster et al. 2004 [in print]). The database used for the analysis includes 18 European countries ${ }^{2}$ where at least two measurement points in time

${ }^{2}$ For historical and analytical reasons, Germany East and West are treated separately. 
during the five major European survey rounds between 1990 and 1999 are available (see table 3 ).

Furthermore, the analysis is restricted to private sector for-profit organisations with more than 200 employees. Thus, overall 20,688 companies are included in this analysis.

\subsection{Devolvement of HR responsibility}

In the Cranet-E survey respondents are asked to identify HR practices of their own organisation in five areas: pay and benefits, recruitment and selection, training and development, industrial relations, and workforce expansion or reduction. In each case respondents rate their organisations whether primary responsibility for major policy decisions rests with line management, line management with personnel or HR function support, the personnel or HR function with line management support, or with the personnel or HR department alone. An index is calculated ranging from 5 points, meaning that the HR department alone decided in all five areas, to 20 points, indicating that in all five areas solely the line managers are the decision makers.

Table 3. Countries included and year of survey

\begin{tabular}{|l|lllll|}
\cline { 2 - 5 } \multicolumn{1}{l|}{} & 1990 & 1991 & 1992 & 1995 & 1999 \\
\hline France & $\bullet$ & $\bullet$ & $\bullet$ & $\bullet$ & $\bullet$ \\
Germany - East & & & $\bullet$ & $\bullet$ & $\bullet$ \\
Germany - West & $\bullet$ & $\bullet$ & $\bullet$ & $\bullet$ & $\bullet$ \\
Great Britain & $\bullet$ & $\bullet$ & $\bullet$ & $\bullet$ & $\bullet$ \\
Sweden & $\bullet$ & $\bullet$ & $\bullet$ & $\bullet$ & $\bullet$ \\
Denmark & $\bullet$ & $\bullet$ & $\bullet$ & $\bullet$ & $\bullet$ \\
Netherlands & & $\bullet$ & $\bullet$ & $\bullet$ & $\bullet$ \\
Norway & & $\bullet$ & $\bullet$ & $\bullet$ & $\bullet$ \\
Switzerland & & $\bullet$ & $\bullet$ & $\bullet$ & $\bullet$ \\
Austria & & & $\bullet$ & $\bullet$ & $\bullet$ \\
Czech Republic & & & $\bullet$ & & $\bullet$ \\
Finland & & & $\bullet$ & $\bullet$ & $\bullet$ \\
Greece & & & $\bullet$ & & $\bullet$ \\
Ireland & & & $\bullet$ & $\bullet$ & $\bullet$ \\
Portugal & & & $\bullet$ & $\bullet$ & $\bullet$ \\
Turkey & & & & $\bullet$ \\
Belgium & & & & & $\bullet$ \\
\hline
\end{tabular}

\subsection{Measures of convergence}

The analyses of directional (type 1) and final convergence (type 2) for the devolvement of responsibility away from central HR specialists towards line management is based on logistic regression models. Time is the primary explanatory variable in these regression models as our basic assumption refers to yearly changes in the response variables. Our regression models also control 
for possible differences in the size of the firm, the sector the company operates in, and foreign ownership. Firms are divided into large (more than 1000 employees), medium (between 501 and 1000 employees), and small (between 201 and 500 employees) companies. Firms are assigned to the primary, secondary or tertiary sectors, depending on their response to one of the survey questions. Finally, a distinction is made between indigenous companies and companies that are under foreign ownership assuming that this makes a crucial difference for the usage of HR concepts and tools.

For directional convergence (type 1), a regression model for each of the countries included is estimated for the response variables. Estimates of the yearly changes in the response variable are obtained, and their significance is assessed by calculating their t-ratios.

For final convergence (type 2), the regression models for each country constitute the basis of the analysis. The regression equation for each country leads to an assumed value for each quarter of a year between 1990 and 1999. This results in individual country values for 40 points in time. For each of these 40 points in time the mean and the standard deviation of all the countries included are calculated. In this way, we are able to determine the 'band-width' of country values for each of these points in time. This 'band-width' is constituted at the upper end by the mean value of all countries plus one standard deviation and at the lower end by the mean value of all countries minus one standard deviation for each point in time. The point of maximum convergence is calculated by determining the point in time with the minimal difference between the mean value of all countries plus one standard deviation and the mean value of all countries minus one standard deviation.

\subsection{Measures of organisational performance}

The relationship between organisational performance and the devolvement of HR responsibility is analysed by using a logistic regression model. In the survey, respondents are asked to estimate organisational performance by comparing their company's gross revenues and costs. In our analysis, a dichotomous variable differentiates between companies with gross revenues ,well in excess of costs' (one item in the questionnaire) and those who rate their performance less good. Since organisational performance is not only influenced by management measures, but also varies due to time based factors like economic growth or decline and country and sector specific factors, we take into account these influences. Hence, for each year logistic regression analyses are conducted separately. Country, sector, size and status as part of a multinational company or not is introduced as controlling variable and are not accountable for differences in organisational performance.

In an additional step, we are also looking more closely at interaction effects that are not covered by logistic regression analysis. CHAID (CHi-square Automatic 
Interaction Analysis) is a statistical tool segmenting samples along specific criteria having a high or low value. These segments differ statistically significant from each other. In our analysis, CHAID identifies segments which contain statistically significant different portions of successful companies. Beyond the devolvement variable other HR practices often mentioned as relevant for organisational performance are included as segmentation variables: decentralisation of HR policy decisions towards ,lower' organisational levels; outsourcing of HR tasks; size of HR department; investment in training and development; information of employees; performance related compensation; use of flexible work practices. In addition, country, size, sector and foreign ownership are included.

\section{Results and discussion}

\subsection{Convergence}

- Directional convergence (type 1)

The first hypothesis refers to the increasing allocation of HR responsibilities to line managers in the sense of directional convergence (see table 4).

The analysed aspect - the distribution of responsibility between members of the HR department and line management - is measured by a composite measure ranging from 5 to 20 (high centralisation vs. high decentralisation). The figures for each country indicate the average yearly change of this composite measure. A positive prefix indicates a development in the same direction as hypothesised, i.e., a movement towards greater responsibility of line management or, in other words, a higher value of the composite measure. For example, in Ireland the positive value of $0.13^{*}$ indicates that there is a statistically significant shift in HR responsibility towards line management of 0.13 composite measure points per year or 1.3 points over the ten year period which is in line with the hypothesis. On the other hand, the value -0.015 for Denmark indicates a statistically not significant development towards increased centralisation, i.e. responsibility for HR management, of 0.015 per year or 0.151 composite measurement points over ten years.

Overall, the countries split half in terms of the direction of the development: 50 per cent move into the expected direction and 50 per cent do not. Only three countries, however, show statistically significant changes, all of them in the direction expected. Over all countries a slight shift towards an increased responsibility of HR departments in the issues analysed can be observed. The mean value of all countries together does not support our hypothesis assuming a decentralisation tendency. On the contrary, we can see a statistically not significant 'back swing' of 0.015 composite measure points per year or 0.15 over a ten year period towards a greater centralisation. 
Table 4. Distribution of responsibility between $H R$ department and line management - yearly change (directional convergence)

\begin{tabular}{|l|l|}
\hline Analysed aspect & $\begin{array}{l}\text { Distribution of responsibility between HR department and line } \\
\text { management }\end{array}$ \\
\hline $\begin{array}{l}\text { Range and } \\
\text { explanation of } \\
\text { scales }\end{array}$ & $\begin{array}{l}\text { Scale range: 5-20 } \\
\text { 5: HR department is primarily responsible for crucial decisions in all five } \\
\text { major HR areas } \\
\text { 20: Line management is primarily responsible for crucial decisions in all } \\
\text { five major HR areas }\end{array}$ \\
\hline $\begin{array}{l}\text { Average value, } \\
\text { all countries } \\
\text { and points in } \\
\text { time }\end{array}$ & \begin{tabular}{l} 
Scale value: 12,6 \\
\hline \multicolumn{1}{|c|}{$\begin{array}{l}\text { Developments between 1990 and 1999 } \\
\text { (values indicate average yearly change) }\end{array}$} \\
\hline HR responsibility shifts from HR departments to line \\
management
\end{tabular} \\
\hline Hypotheses about developments & $+0,045$ \\
\hline Austria (2) & $-0,096$ \\
\hline Belgium (2) & $-0,089$ \\
\hline Czech Republic (2) & $-0,015$ \\
\hline Denmark (4) & $+0,003$ \\
\hline Finland (3) & $-0,151$ \\
\hline France (5) & $+0,038$ \\
\hline Germany - East (3) & $-0,027$ \\
\hline Germany - West (5) & $-0,039$ \\
\hline Great Britain (5) & $-0,150$ \\
\hline Greece (2) & $+0,130 *$ \\
\hline Ireland (3) & $+0,029$ \\
\hline Netherlands (4) & $+0,199 *$ \\
\hline Norway (4) & $-0,077$ \\
\hline Portugal (2) & $-0,175$ \\
\hline Spain (5) & $+0,064 *$ \\
\hline Sweden (5) & $+0,034$ \\
\hline Switzerland (3) & $+0,005$ \\
\hline Turkey (3) & $-0,015$ \\
\hline $\begin{array}{l}\text { Average of developments, all } \\
\text { countries }\end{array}$ & $50 \%$ \\
\hline $\begin{array}{l}\text { Proportion of countries with } \\
\text { developments } \\
\text { hypotheses }\end{array}$ & according \\
\hline
\end{tabular}

${ }^{+}$The values in brackets indicate the number of measurement points in time

* significant regression coefficient at the .05 level, one-tailed test of hypotheses 
- Final convergence (type 2)

Confirming the second hypotheses dealing with final convergence hypothesis countries become more similar over time - would require a movement towards a common end point. By the operationalisation we chose, this would be indicated by a decreasing 'band width' of the mean country values plus/minus one standard deviation for each point in time. The results are presented in table 5.

The upper part of the table provides the overall view of the development across all 18 countries over time. The solid line in the middle of the grey band indicates the average absolute value of the composite measure for all countries for a given time and the direction of change over time. It starts with 12.9 composite measure points. At the end of time span analysed, this value has gone down to 12.79 which is necessarily in line with the findings of the discussion about directional convergence.

The grey band itself shows the development of the heterogeneity of the country values over time. The 'waist' of the grey band where there is the least bandwidth indicates the point of maximum convergence. Contrary to our hypothesis regarding the relative share of responsibility between personnel and line managers, European firms show the least divergence between 1991 and 1992 where the 'waist' of the band is smallest. Thus, despite continuing recommendations and prescriptions for a devolvement of HR responsibility to line management during the 1990s, developments across European countries diverged during the 1990s.

The lower part of the table uses the overall view as the background for illustrating the developments in the various countries. The developments for all the 18 countries included are illustrated by regression lines for each country. Again, absolute level and direction of developments can be seen for each country. In addition, it illustrates the great variety of developments in the various countries where increases, relatively stable situations as well as decreases in the value of the composite measure can be seen.

\subsection{Devolvement of $H R$ responsibilities and success}

The third hypotheses deals with the link between the devolvement of HR responsibilities and organisational performance. The results of a logistic regression analysis can be found in table 6 .

In 1995 and 1999, there is no statistically significant correlation between devolvement of HR responsibility and success. In 1992, the only year where a significant correlation exists, the correlation is not in the expected direction. The odds-ratio of 0.81 indicates that a change of responsibility towards line management of 1 index point reduces rather than, as expected in the hypothesis, increases the odds of organisational success by 19 per cent. Thus, successful companies have given less responsibility to line management over time. Thus, 
the empirical results do not follow our hypothesis that a greater devolvement of HR responsibilities away from HR specialist departments towards line management is positively related to organisational performance. In the years analysed, the relationship either is statistically not significant or in a direction contrary to our expectations.

The results of the CHAID analysis basically confirm these results. No significant effects regarding the link between devolvement of HR responsibility to line management and organisational performance can be detected.

However, CHAID analysis points towards another important aspect of the link between HR practices and organisational performance: quite different HR configurations, i.e. specific combinations of HR practices, are positively related to organisational performance. All the segments printed in bold contain such specific configurations which are linked with organisational success (see table 7).

Table 5. Country differences in the distribution of responsibility between HR department and line management (final convergence) - overall and country specific picture

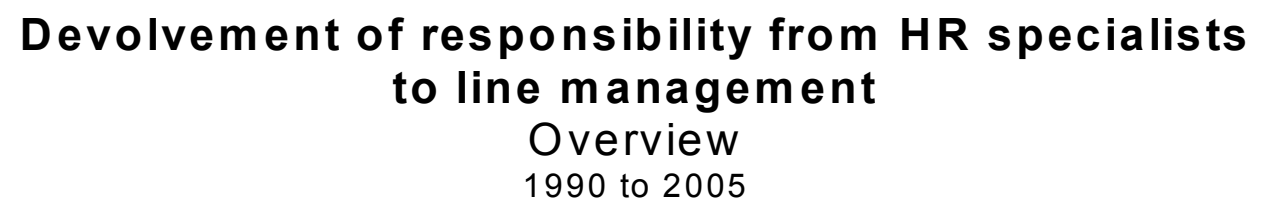

Devolvement of responsibility from HR specialists to line management

Overview

1990 to 2005

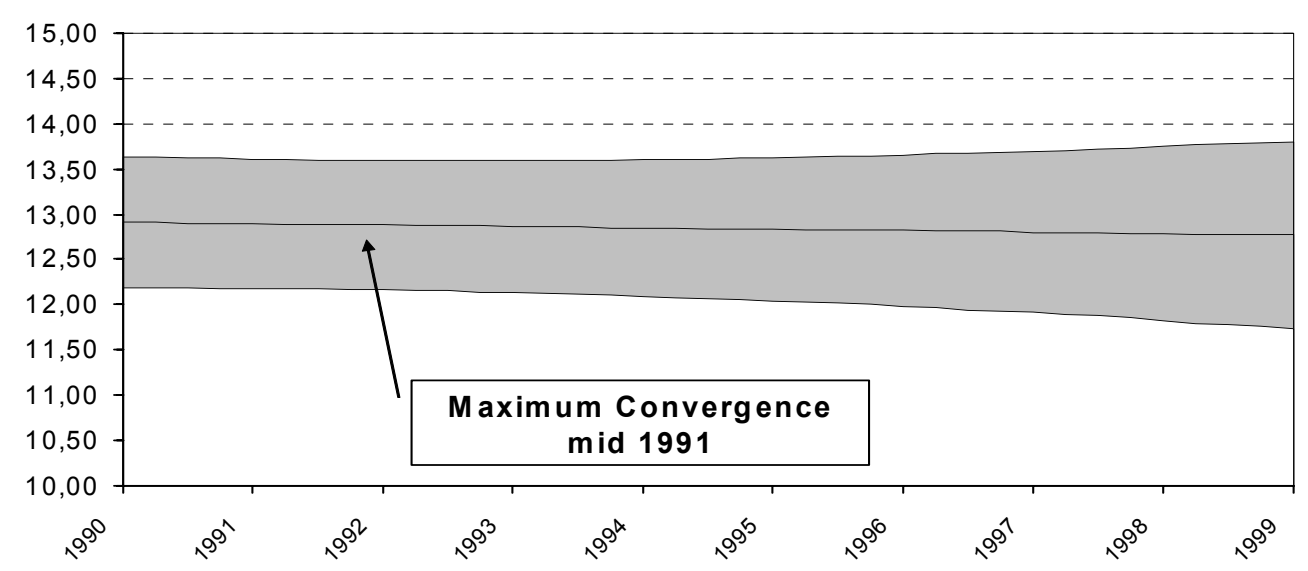




\section{Devolvement of responsibility from HR specialists to line management \\ 18 Countries \\ 1990 to 2005}

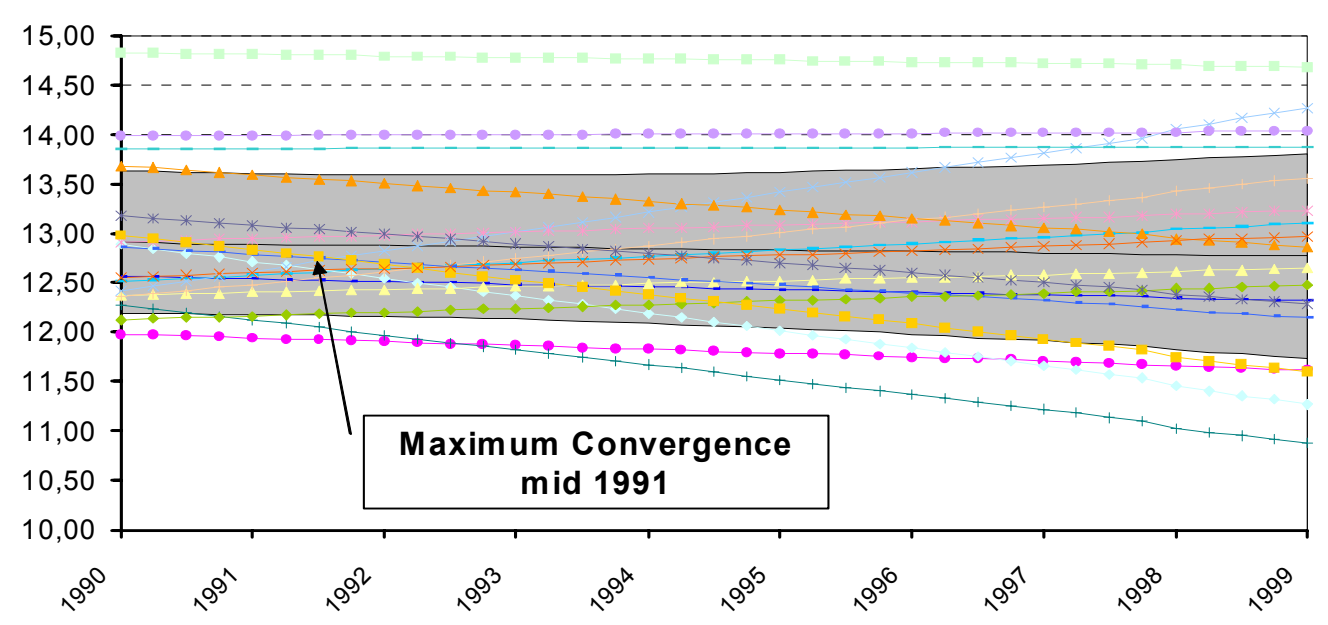

Table 6. Devolvement of $H R$ responsibilities from specialists to line management and organisational performance-logistic regression

\begin{tabular}{|l|l|l|l|}
\cline { 2 - 4 } \multicolumn{1}{l|}{} & 1992 & 1995 & 1999 \\
\hline Controlling variables & & & \\
\hline Country & $\mathrm{X}^{1}$ & $\mathrm{X}$ & $\mathrm{X}$ \\
\hline Sector & $\mathrm{X}$ & $\mathrm{X}$ & \\
\hline Size & & $\mathrm{X}$ & $\mathrm{X}$ \\
\hline Link to Multinational Company & $\mathrm{X}$ & & \\
\hline Regression variables & & & \\
\hline $\begin{array}{l}\text { Distribution of responsibility between } \\
\text { HR specialists and line management }\end{array}$ & 0.82 & & \\
\hline
\end{tabular}

1 For controlling variables (country, sector, size, linked to multinational company) only the existence of a significant effect is indicated.

The table shows that - in decreasing absolute numbers and traceable by following the 'tree' along the bold printed alternatives at each of the 'crossroads' - three basic HR configurations exist that 'contain' a significantly greater portion of successful companies: 
- Companies with performance related incentive schemes and more than 500 employees

- Companies with no or few performance related incentive schemes and highly centralised policy determination, i.e., all policies are determined by the (international) headquarter. In this case, the existence of performance related incentive schemes or - if not available - a high importance of innovation for organisational success in addition make a crucial difference

- Companies with few or many performance related incentive schemes and a more decentralised way of policy determination - if quality is strategically important for organisational success, HR functions are outsourced and where service is not so critical

While a detailed analysis of these goes beyond the scope of this paper, they make one thing clear: There is no clear and stable link between organisational performance and devolvement of HR responsibilities. Likewise, there is no 'magic tool' or 'one best way' of using different HR practices. Very different configurations of HR tools and concepts are linked with high organisational performance.

\section{Discussion}

Slight tendencies towards 'recentralisation' and increasing divergence go against our hypotheses but confirm latest trends in HR as reflected, e.g., in oral reports of head-hunters and HR-consultants. The growing importance of human resources and training and development, the introduction of standardised and sometimes complicated HR related tools like, e.g., performance related pay systems strengthen the position of central HR. They demand a good amount of knowledge and time often not to be found in line management. In the past, many companies did not place so much importance to the HR function. Smaller companies very often did not even have something like a formal personnel department. Rapidly growing companies of the new economy often had no time to deal with questions of formal organised HR functions. Instead, line managers with the day-to-day contact with employees were trying to solve the HR problems. As these companies reach a certain size or phase of differentiation, HR becomes more complicated. Thus, specialists dealing in depth with these kind of problems are needed. Again, this strengthens the existing HR departments or fosters the establishments of central personnel functions.

Further explanations are possible at the country level. Ireland, Norway and Sweden seem to be continually on the way to decentralisation. Approximately half of the other countries, however, show - though statistically not significant - the reverse trend. 
From a cultural point of view we can identify a Northern European cluster, showing a tendency to a decentralisation of HRM activities to line managers. This goes in line with Brewster and Larsen (2000a: 29) who identify Ireland, the UK, the Netherlands, Sweden, Denmark, and Finland as countries of Northern Europe where ,the commonalities between the approaches to HRM are, in comparison to other parts of Europe and the world, greater than the differences." There is survey evidence (cf. Brewster/Söderström 1994; Brewster et al. 1997; Brewster/Larsen 2000b) confirming a leading position in the decentralisation of HRM activities of the Northern European countries at different points of time. There is one exception, Denmark, holding a even more leading position within the Northern European cluster of other studies whereas in our study Denmark does not show such a development. But as the Danish result in our study is statistically not significant, there may be other influences being responsible for this outcome. Furthermore it is important to note that the different countries are not starting from the same position.

Nevertheless, the question remains why Northern Europe seems to be more on a track to decentralisation. Spyropoulos (1996) contrasts the Northern European countries, where freedom of association and collective bargaining rights are effectively ensured by legislation, with several Southern European countries, where such rights are absent or less effectively protected. This goes in line with a significant legislative involvement in employment matters and the importance of equal opportunities (see also Brewster/Larsen 2000a). Considering the five issues examined in our study (pay and benefits, recruitment and selection, training and development, industrial relations, and expansion and reduction of the workforce) we can see that in some way they are all subject to one of these regulations. This means that there is less freedom within the companies. We therefore assume that such a clearly defined framework in personnel matters may be favourable to allocate personnel responsibilities to e.g. line mangers because it will be easier for them to handle these matters which so far have not been their daily business.

Likewise, Northern European countries seem to be quite similar when looked at through a cultural lens. According Hofstede's well known culture study Northern European countries are very high in femininity (Hofstede 1980). He also stresses lower power distance positions of the Northern countries which indicate a more democratic way of thinking and acting within organisations. Other characteristic features of the Northern European cluster are a substantial state-owned sector, the central role of the government in setting standards for wages and working conditions, rather high levels with trade union membership, and strong educational backgrounds. 
Table 7. Devolvement of $H R$ responsibilities from specialists to line management and organisational performance-CHAID analysis

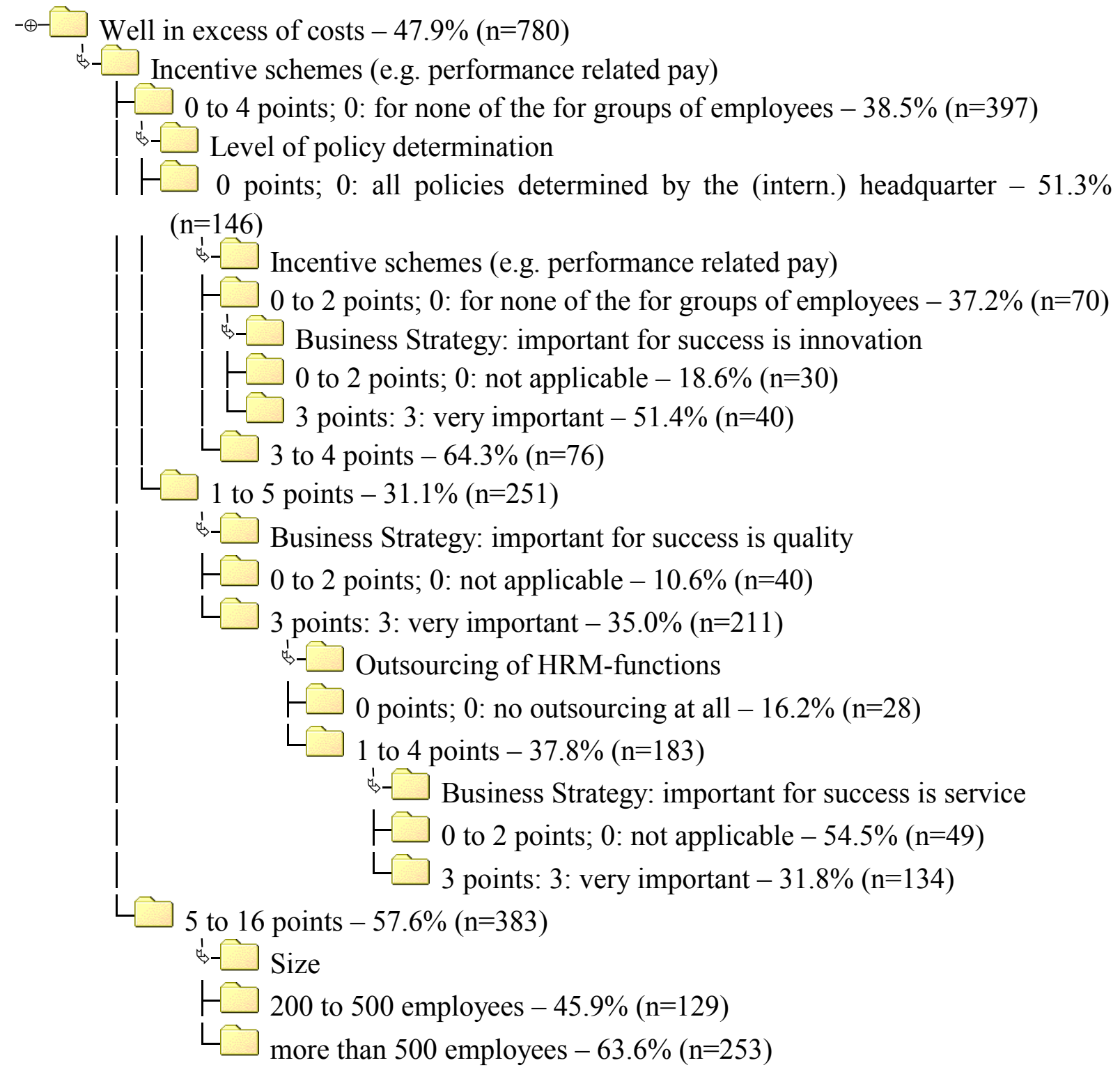

In terms of organisational performance, a number of reasons possibly contribute to the absence of a clear and continuous link with the devolvement of responsibility. First, as outlined above, there seems to be a 'back swing' towards recentralisation emerging. It may well be the case that especially leading edge and economically successful companies are a substantial part of that development. Second, as the CHAID analysis has shown, it is never only one factor that contributes to organisational performance but different configurations of HR practices. Third, and related to the argument before, organisational performance has multiple causes. The devolvement of responsibilities may be just one among numerous influencing factors that play a role here. Nevertheless, it seems remarkable that unlike other factors like 
performance related pay, outsourcing or decision procedures on policy issues a very prominent factor in the HR discussion has no clear statistical effect here.

\section{Concluding remarks}

There are a number of lessons that can be learned from this analysis. They apply to HR academics and practitioners in general and those in Central and Eastern European (CEE) countries in particular.

First, there is no clear trend towards convergence in the area analysed here. Additional research suggests that this is no exception but rather the rule - stasis seems to be at least as frequent as convergence or divergence (see, e.g., Mayrhofer et al. 2002; Müller et al. 2001; Mayrhofer et al. 2004 [in print]). Thus, there is no immediate threat to diversity and a national identity or way of doing things, at least as far as HR is concerned.

Second, the picture emerging is rather diverse and by no means complete. At a theoretical as well as at an empirical level we do not adequately understand the forces and dynamics of change that affect organisations in the developing Europe. This is especially true for the CEE countries where these changes are, at least in part, even greater. Due to their history in a non-market economy environment for several decades and the ongoing transition process it will be especially interesting to see how convergence or divergence processes develop in these countries. The current analysis can contribute little to this question due to a lack of data. However, in the coming round of the Cranet survey more CEE will be included. Thus, an empirical contribution to this issue can be expected.

Third, a good deal of scepticism about so called best practice models seems to be justified. This analysis as well as other evidence (e.g., Müller-Camen et al. 2003) suggests that there is no 'one best way' of managing HR to contribute to organisational performance. This is not only in line with much of organisational theory which - after many years of research within a contingency theory framework - concludes that there is no clear answer to any 'ideal' organisational configuration (see, e.g., Kasper et al. 2002: 59 ff.). It is also an important message to CEE countries. Often, organisations in these countries are under a lot of pressure to import and implement 'good', 'proven' and 'superior' models of Western management. While it would be of little value to deny the importance of constantly improving and changing national management practices, our results carry an important caveat: various configurations of HR practice and, we dare to claim, management in general can be linked with good organisational performance. This allows for a greater variety of solutions than often claimed.

Although the evidence is clearly limited, it suggests that theoretically as well as empirically the issue of convergence and divergence is more complex than assumed. This study uses quasi-longitudinal data and questions some of the 
seemingly 'clear' assumptions about the increasing convergence of management practices as well as their importance for organisational performance. As so often, however, more research is clearly needed.

\section{References}

Brewster, C. (1994a): Towards a 'European' Model of Human Resource Management. In: Journal of International Business Studies, (1): 1-24.

Brewster, C. (1994b): European HRM: Reflection of, or Challenge to, the American Concept? In: Kirkbride, P.S. (ed.): Human Resource Managment in Europe. London et al.

Brewster, C./Hegewisch, A. (ed.) (1994): Policy and Practice in European Human Resource Management. The Price Waterhouse Cranfield Survey. London, New York.

Brewster, C./Larsen, H.H. (2000a): The Northern European Dimension. A Distinctive Environment for HRM. In: Brewster, C./Larsen, H.H. (ed.): Human Resource Management in Northern Europe. Oxford: 24-38.

Brewster, C./Larsen, H.H. (2000b): Flexibility in HRM. Contradictions in Organizational Survival. In: Brewster, C./Larsen, H.H. (ed.): Human Resource Management in Northern Europe. Oxford: 125-146.

Brewster, C./Larsen, H.H./Mayrhofer, W. (1997): Integration and Assignment: A Paradox in Human Resource Management. In: Journal of International Management, 3(1): 1-23.

Brewster, C./Mayrhofer, W./Morley, M. (ed.) (2000): New Challenges in European Human Resource Management. London.

Brewster, C./Mayrhofer, W./Morley, M. (ed.) (2004): Human Resource Management in Europe - evidence of convergence? Oxford.

Brewster, C./Söderström, M. (1994): Human Resources and Line Management. In: Brewster, C./Hegewisch, A. (ed.): Policy and Practice in European Human Resource Management. London: 51-67.

Chakravarthy, B./Gargiulo, M. (1998): Maintaining Leadership Legitimacy in the Transition to New Organizational Forms. In: Journal of Management Studies, 35(4): 437-456.

Chandler Jr., A.D. (1962): Strategy and Structure. Boston.

Chandler Jr., A.D. (1977): The Visible Hand. The Managerial Revolution in American Business, Cambridge (Mass.).

Czinkota, M. R./Ronkainen, I. A./Moffet, M.H. (1994): International Business. 3. Fort Worth et al

DiMaggio, P.J./Powell, W.W. (1983): The Iron Cage Revisited: Institutional Isomorphism and Collective Rationality in Organizational Fields. In: American Sociological Review, 48: 147-160.

Drumm, H.-J. (1996): Das Paradigma der Neuen Dezentralisation. In: Die Betriebswirtschaft, 56(1): 7-20.

Engwall, L. (2000): The Globalisation of Management: Standardisation Processes in Management with an Illustration from Scandinavia. In: Zeitschrift für Betriebswirtschaft, Ergänzungsheft(1): 1-22. 
Fayol, H. (1916): Administration industrielle et générale. Paris.

Fayol, H. (1985): General Principles of Management (Orig. 1949). In: Pugh, D. S. (Hg.): Organization Theory. Selected Readings. Harmondsworth et al.: S.135-156.

Fombrun, C.J. (1986): Structural Dynamics within and between Organizations. In: Administrative Science Quarterly, 31(3): 403-421.

Frech, M./Schmidt, A./Heimerl-Wagner, P. (1996): Management - drei klassische Konzepte und ihre Befunde. In: Eckardstein, D.v./Kasper, H./Mayrhofer, W. (ed.): Management. Stuttgart: 221-255.

Gooderham, P.N./Nordhaug, O./Ringdal, K. (1999): Institutional and Rational Determinants of Organizational Practices: Human Resource Management in European Firms. In: Administrative Science Quaterly, 44: 507-531.

Hamel, G./Prahalad, C.K. (1994): Competing for the Future. Boston.

Hofstede, G. (1980): Culture's consequences. Beverly Hills, CA.

Hollingsworth, J.R./Boyer, R. (1997): Coordination of Economic Actors and Social Systems of Production. In: Hollingsworth, J.R./Boyer, R. (ed.): Contemporary Capitalism. Cambridge

Kasper, H./Heimerl, P./Mühlbacher, J. (2002): Strukturale und prozessorientierte Organisations-formen. In: Kasper, H./Mayrhofer, W. (ed.): Personalmanagement, Führung, Organisation. 3 ed. Wien: 19-94.

Kennoy, T. (1990): HRM: A Case of the Wolf in Sheep's Clothing. In: Personnel Review, 19(2): 3-9.

Kerr, C./Dunlop, J./Harbison, F./Myers, C. (1960): Industrialism and Industrial Man. Cambridge, MA.

Kidger, P.J. (1991): The Emergence of International Human Resource Management. In: International Human Resource Management, 2(2): 149-163.

Kostova, T./Roth, K. (2002): Adoption of an organizational practice by subsidiaries of multinational cororations: institutional and relational effects. In: Academy of Management Journal, 45(1): 215-233.

Locke, R./Piore, M./Kochan, T. (1995): Introduction. In: Locke, R./Kochan, T./Piore, M. (ed.): Employment Relations in a Changing World Economy. i-xviii.

Mayrhofer, W. (1999): Personalpolitiken und -strategien im internationalen Vergleich. In: Elsik, W./Mayrhofer, W. (ed.): Strategische Personalpolitik. München, Mering: 27-46.

Mayrhofer, W./Morley, M./Brewster, C. (2004): Convergence, stasis, or divergence? In: Brewster, C./Mayrhofer, W./Morley, M. (ed.): European Human Resource Management - Convergence or Divergence. London et al.

Mayrhofer, W./Müller-Camen, M./Ledolter, J./Strunk, G./Erten, C. (2002): The Diffusion of Management Concepts in Europe - Conceptual Considerations and Longitudinal Analysis. In: Journal of Cross-Cultural Competence \& Management, 3: 315-349.

Meyer, J.W./Rowan, E. (1977): Institutionalized organizations: Formal structure as myth and ceremony. In: American Journal of Sociology, 83: 340-363.

Müller, M. (1999): Unitarism, Pluralism and Human Resource Management in Germany. In: Management International Review, 39(Special Issue, 3): 125-144. 
Müller, M./Mayrhofer, W./Ledolter, J./Erten, C./Strunk, G. (2001): Neue Formen der Arbeitsorganisation in Europa -eine empirische Studie. In: Journal für Betriebswirtschaft, 51(5-6): 265-277.

Müller-Camen, M./Mayrhofer, W./Ledolter, J./Strunk, G./Erten, C. (2003): Unternehmenserfolg und Personalmanagement - Eine international vergleichende empirische Analyse. In: Schwaiger, M./Harhoff, D. (eds.): Empirie und Betriebswirtschaft - Entwicklungen und Perspektiven. Stuttgart: 331-349.

Scholz, C. (1995): Die virtuelle Personalabteilung: Ein Denkmodell für das Jahr 2000? In: Personalführung, (5): 398-403.

Schuler, R.S. (1990): Repositioning the Human Resource Function: Transformation or Demise? In: Academy of Management Executive, 4(3): 49-60.

Sparrow, P./Hiltrop, J.M. (1997): Redefining the Field of European Human Resource Management: A Battle between National Mindsets and Forces of Business Transformation? In: Human Resource Management, 36(2): 201-219.

Spyropoulos, G. (1996): Regulation of Direct Participation in Europe. In: European Participation Monitor, EFILWC(12).

Taylor, F.W. (1919): Die Grundsätze wissenschaftlicher Betriebsführung, Nachdruck der Original-Ausgabe. München.

Walker, J.W. (1989): Human Resource Roles for the 1990s. In: Human Resource Planning, 12(1): 55-61.

Weber, M. (1980): Wirtschaft und Gesellschaft. 5., rev. Aufl. (Studienausgabe). Tübingen.

Weber, M. (1988 (Orig. 1917)): Der Sinn der "Wertfreiheit" der soziologischen und ökonomischen Wissenschaften. In: Weber, M. (ed.): Gesammelte Aufsätze zur Wissenschaftslehre. Tübingen: 489-540.

Whitley, R.D. (1994): Dominant Forms of Economic Organization in Market Economics. In: Organization Studies, 15(2): 153-182.

Whittington, R./Pettigrew, A./Peck, S./Fenton, E./Conyon, M. (1999): Change and Complemen-tarities in the New Competitive Landscape: A European Panel Study. In: Organization Science, 10(5): 583-600.

Williamson, O.E. (1975): Markets and Hierarchies. New York.

Zenger, T. R./Hesterly, W.S. (1997): The Disaggregation of Corporations: Selective Intervention, High-powered Incentives, and Molecular Units. In: Organization Science, 8(3): 209-222 